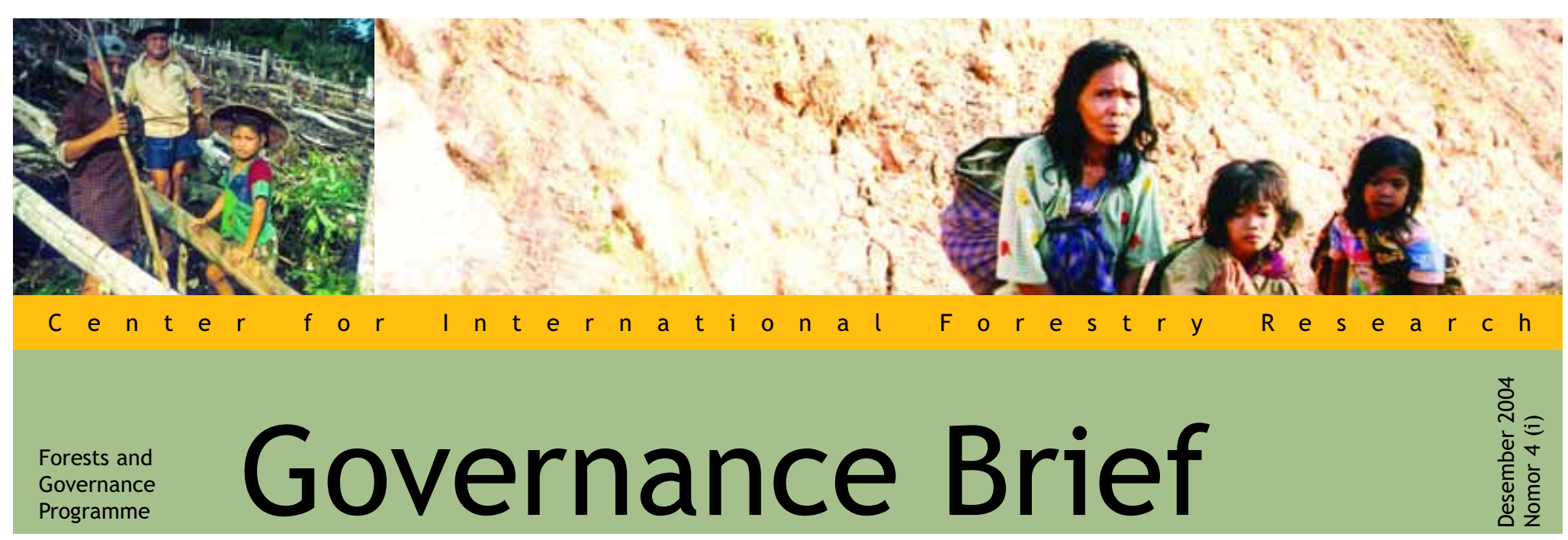

\title{
Mengapa kawasan hutan penting bagi penanggulangan kemiskinan di Indonesia?
}

\author{
Eva Wollenberg, Brian Belcher, Douglas Sheil, Sonya Dewi, Moira Moeliono
}

Indonesia adalah salah satu dari 70 negara yang sepakat menjadikan pengentasan kemiskinan sebagai prioritas kebijakan utama melalui Strategi Penanggulangan Kemiskinan'. Strategi tersebut memang berguna sebagai arahan, tetapi masih ada berbagai kekurangannya. Di banyak negara, termasuk Indonesia, ciri khusus kemiskinan di kawasan hutan dan peran potensial hutan bagi pengentasan kemiskinan masih kurang diperhatikan.

Bappenas (Badan Perencanaan Pembangunan Nasional) dan KPK (Komite Penanggulangan Kemiskinan) dengan berkonsultasi dengan banyak organisasi lain, termasuk yang berkepentingan dengan hutan, sedang merevisi rancangan strategi Indonesia dan menyusun Rencana Jangka Menengah dengan penekanan masalah kemiskinan. Draft Strategi Nasional Penanggulangan Kemiskinan (SNPK atau dalam bahasa Inggris disebut Poverty Reduction Strategy Paper atau PRSP) diharapkan selesai pada bulan Januari 2005 dan Rencana Jangka Menengah (RJM) akan diusulkan pada MPR pada bulan Januari 2005. Dalam tulisan ini kami menyediakan informasi untuk memahami kemiskinan di hutan sebagai dukungan bagi proses tersebut.

Mengapa kemiskinan dan pengentasan kemiskinan di kawasan hutan penting bagi SNPK dan usaha-usaha pengentasan kemiskinan lain di Indonesia?

(1) Masyarakat yang tinggal di hutan merupakan salah satu kelompok miskin terbesar di Indonesia. Di luar Jawa, kebanyakan masyarakat pedesaan tinggal di dalam atau di sekitar kawasan hutan negara. Sekitar 48,8 juta orang tinggal pada lahan hutan negara dan sekitar 10,2 juta di antaranya dianggap miskin ${ }^{2}$. Selain itu ada 20 juta orang yang tinggal di desa-desa dekat hutan dan enam juta orang di antaranya memperoleh sebagian besar penghidupannya dari hutan ${ }^{3}$.

\footnotetext{
Pada tahun 1999, IMF dan Bank Dunia menetapkan penyusunan strategi demikian sebagai syarat bagi negara-negara berpendapatan rendah untuk memperoleh bantuan keuangan. Draft Strategi Nasional Penanggulangan Kemiskinan (SNPK) dibutuhkan untuk memperoleh bantuan dari International Development Association (IDA), Fasilitas Pengentasan Kemiskinan dan Pertumbuhan (Poverty Reduction and Growth Facility atau PRGF) IMF dan Initiatif Negara-negara miskin berhutang besar (Heavily Indebted Poor Countries atau HIPC), yang merupakan kesepakatan antar pemberi hutang untuk meringankan hutang Negara-negara miskin. Untuk keterangan lebih lengkap lihat http://www.worldbank.org/poverty/strategies.
}

${ }^{2}$ Brown, T. 2004 Analysis of population and poverty in Indonesia's forests. Draft. Natural Resources Management Program Report, Jakarta.

${ }^{3}$ Sunderlin, W.D., Resosudarmo, I.A.P., Rianto, E. dan Angelsen, A. 2000. The effect of Indonesia's economic crisis on small farmers and natural forest cover in the outer islands. Occasional Paper 29(E). Bogor, CIFOR. 


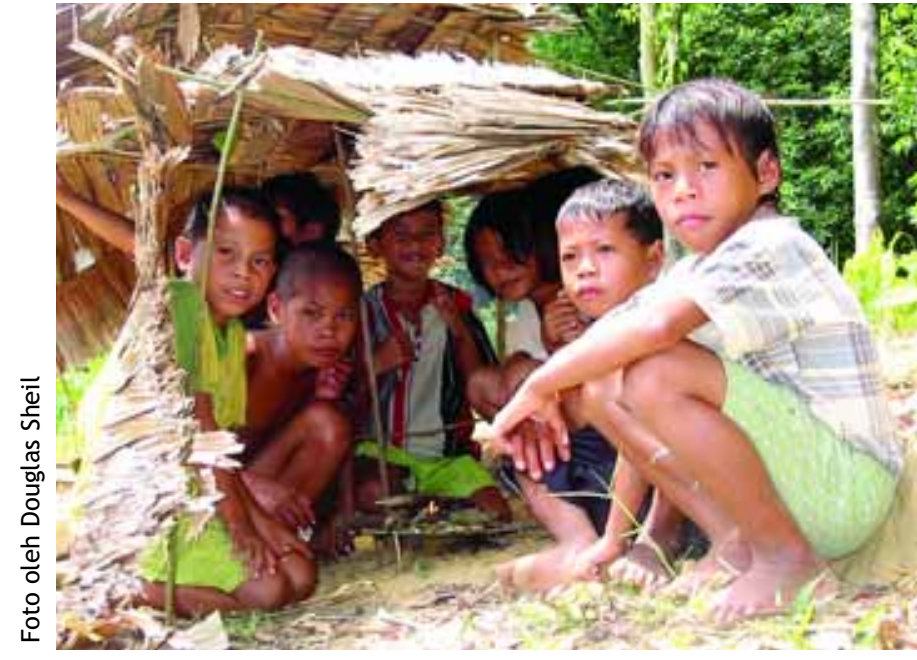

(2) Masyarakat yang tinggal di hutan cenderung miskin secara menahun. Tidak adanya prasarana, sulitnya komunikasi dan jauhnya jarak hutan dari pasar, sarana kesehatan dan pendidikan sangat membatasi pilihan sumber penghidupan. Akibatnya, sulit bagi masyarakat miskin di hutan untuk dapat keluar dari kemiskinan. Lagi pula biaya penyediaan pelayanan pemerintah bagi daerah-daerah terpencil sangat tinggi.

(3) Hutan merupakan sumber daya penting bagi orang miskin. Hutan mutlak diperlukan sebagai sumber pangan, bahan bangunan dan bahan lain bagi rumah tangga termiskin di kawasan hutan. Hutan memungkinkan peladang mempertahankan kesuburan tanah dan pengendalian gulma yang diperlukan untuk memenuhi kebutuhan pangan. Hutan merupakan jaring pengaman ekonomi ketika panen gagal atau pekerjaan upahan tidak ada. Bagi banyak keluarga, berjual hasil hutan dan hasil wanatani (agroforest) merupakan sumber uang utama untuk dapat membiayai sarana produksi pertanian, sekolah dan kesehatan. Ada lebih dari 90 hasil hutan bukan kayu yang diperjualbelikan di Indonesia. Diperkirakan ada lebih dari 50,000 petani di Kalimantan yang menggantungkan penghidupan pada usaha rotan, 18,000 keluarga di Sumatera Utara pada benzoin (Styrax benzoin), hampir semua rumah tangga di Krui terlibat usaha damar (Shorea javanica) dan ribuan keluarga di Kalimantan Timur terlibat dalam usaha gaharu (Aquilaria spp.).
(4) Hutan menyediakan pelayanan ekosistem yang mendasar bagi penghidupan dan kesejahteraan penduduk di sekitar hutan, khususnya mereka yang miskin. Hutan melindungi daerah tangkapan yang menyediakan air bersih, mengurangi kerusakan akibat banjir, menstabilkan lereng dan mencegah longsor. Di daerah yang lebih kering, hutan melindungi mata air, dan hutan pegunungan mengikat air yang kemudian mengalir ke sungai yang menghidupi daerah rendah. Hutan bakau melindungi daerah pesisir dari erosi pantai dan memegang peran ekologi dalam memelihara populasi ikan. Kehilangan penutupan hutan ternyata berpengaruh terhadap kesehatan, misalnya meningkatnya penyakit yang ditularkan vektor seperti malaria dan demam berdarah. Hutan juga merupakan dasar nilai-nilai budaya dan spiritual yang penting untuk memelihara persatuan sosial dan harga diri. Terlalu sering nilai-nilai perlindungan hutan ini tidak diperhitungkan dan ketika hutan tidak ada lagi yang menderita adalah mereka yang miskin.

(5) Meningkatnya permintaan internasional akan produk alami, sertifikasi dan pasar 'hijau' disertai dengan membaiknya prasarana pasar membuka peluang usaha jenis lain bagi masyarakat di kawasan hutan. Peluang ini masih belum banyak dimanfaatkan di Indonesia.

(6) Lahan di hampir semua kawasan hutan dikuasai oleh negara. Berjuta-juta masyarakat pedesaan yang tinggal di kawasan hutan di luar Jawa, secara legal dianggap penduduk liar atau illegal. Mereka tidak memiliki kepastian akses terhadap lahan, sedangkan lahan merupakan sumber daya utama bagi petani. Ada banyak bukti taraf hidup pedesaan meningkat jika masyarakat mempunyai kepastian hak terhadap lahan yang cukup. Ketiadaan penegakan hukum dan bertahannya adat-istiadat setempat berarti bahwa kebanyakan orang menemukan cara pemanfaatan sumber daya hutan untuk memenuhi kebutuhannya. Meskipun demikian merebaknya konflik dari waktu ke waktu menunjukkan bahwa akses terhadap lahan di kawasan hutan merupakan permasalahan menahun yang berpotensi gawat, seperti pada waktu penghancuran kopi rakyat di kawasan hutan negara di Manggarai tahun 2003 dan 2004. Desentralisasi, yang memperluas wewenang pemerintah 
kabupaten tanpa kejelasan peran lembaga dan program nasional di kabupaten, telah memperbesar kerancuan penguasaan dan tata guna lahan. Departemen Kehutanan dan pemerintah setempat sangat perlu dilibatkan dalam reforma agraria untuk memberi kepastian akses bagi masyarakat miskin di kawasan hutan.

(7) Sumber daya yang dipanen, ditambang atau dimanfaatkan dari kawasan hutan bernilai sangat besar. Kayu jati (Tectona grandis) bulat dan gergajian yang diperdagangkan di dalam negeri saja sudah bernilai USD 87 juta pada tahun $2001^{4}$. Pada tahun 2002 nilai ekspor pulp mencapai USD 706,8 juta dan nilai kayu gergajian dari semua jenis USD 363 juta. Akan tetapi masyarakat lokal hanya memperoleh sedikit keuntungan dari sumber daya yang bernilai begitu besar. Hampir tidak ada usaha di tingkat kebijakan sekalipun yang mengalokasi sebagian keuntungan tersebut untuk penanggulangan kemiskinan atau untuk investasi jangka panjang dalam aset manusia, keuangan, fisik ataupun aset alami. Bahkan sebaliknya terjadi. Dampak buruk terhadap lingkungan dan sosial akibat perkembangan lalu ditanggung oleh masyarakat setempat. Pembuat kebijakan cenderung memprioritaskan keuntungan ekonomi jangka pendek dengan mengorbankan hutan alam.

(8) Sejak tahun 1960-an, kebijakan penanggulangan kemiskinan di Indonesia kebanyakan didasarkan pada keadaan pedesaan di luar hutan, khususnya di Jawa. Kebijakan-kebijakan tersebut mengabaikan atau tidak berarti bagi masyarakat di kawasan hutan. Misalnya, pada tahun 1960an, ketika undang-undang pertanahan memungkinkan masyarakat mendaftarkan tanah miliknya, peladang tidak diakui sebagai petani, sedangkan informasi mengenai persyaratan untuk mendaftarkan tanah tidak sampai di daerah pelosok Indonesia.

(9) Bantuan sektoral oleh Departemen Kehutanan tidak memberikan dampak yang berarti. Departemen Kehutanan tidak mempunyai keahlian dan mandat untuk menanggulangi kemiskinan. Kepentingan konservasi dan produksi kayu sering bertabrakan langsung dengan kebutuhan penghidupan masyarakat setempat. Program Bina Desa yang kemudian berkembang menjadi PMDH (Pembinaan Masyarakat Desa

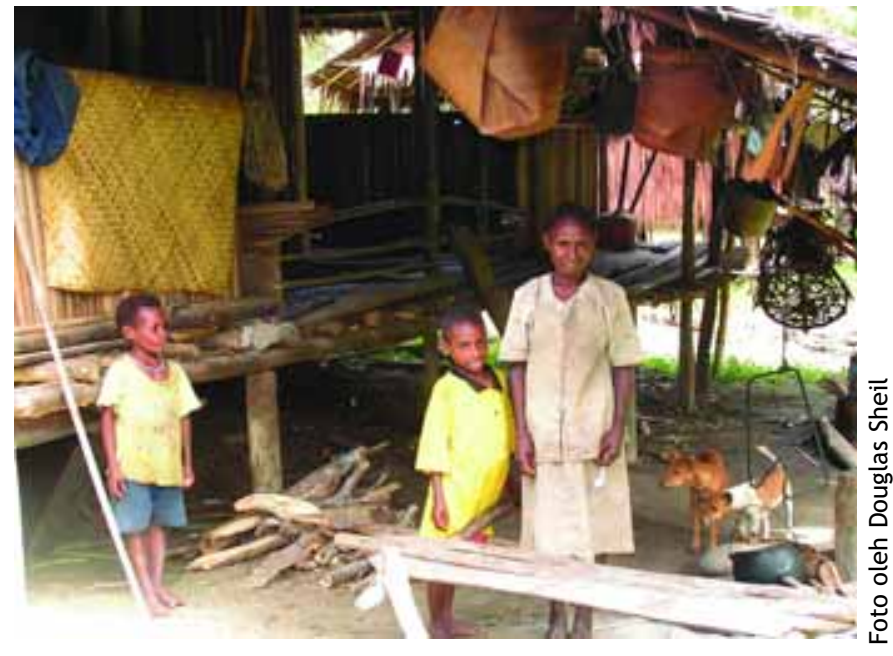

Hutan) yang dilaksanakan oleh HPH (Hak Pengusahaan Hutan) menyediakan bantuan sekedarnya, tidak merata dan jangka pendek. Bantuan pembangunan melalui sektor kehutanan saja akan memperbesar ketinggalan daerah-daerah ini. Pembangunan masyarakat di kawasan hutan dikhawatirkan akan terlupakan bila tidak dipadukan dalam program pembangunan yang lebih luas.

(10) Meningkatnya kemiskinan dan kesenjangan antara kaya dan miskin menciptakan keadaan sosial yang genting dan dapat berakibat meningkatnya pencurian, kekerasan, ketidakpastian dan pergolakan. Khususnya di kawasan hutan, desentralisasi telah merangsang perkembangan ekonomi yang cepat yang disertai tertumpuknya kekayaan di tangan beberapa orang sedangkan orang lain tidak merasakan keuntungan apa-apa. Kesenjangan ini telah berakibat berkurangnya persatuan dan kekompakan sosial di beberapa daerah dan di masa datang dapat berakibat meningkatnya potensi gejolak politik dan sosial.

Kelima butir pertama terkait kebutuhan dan peluang masyarakat setempat dan pemanfaatan sumber daya hutan oleh mereka. Kelima butir terakhir menunjukkan perlunya perubahan kebijakan yang diperlukan untuk memenuhi kebutuhan masyarakat tersebut.

\footnotetext{
Maturana, J. 2004. Learning more about private teak plantations in Java: proper incentives to promote better income for the poor. Unpublished Report.
} 


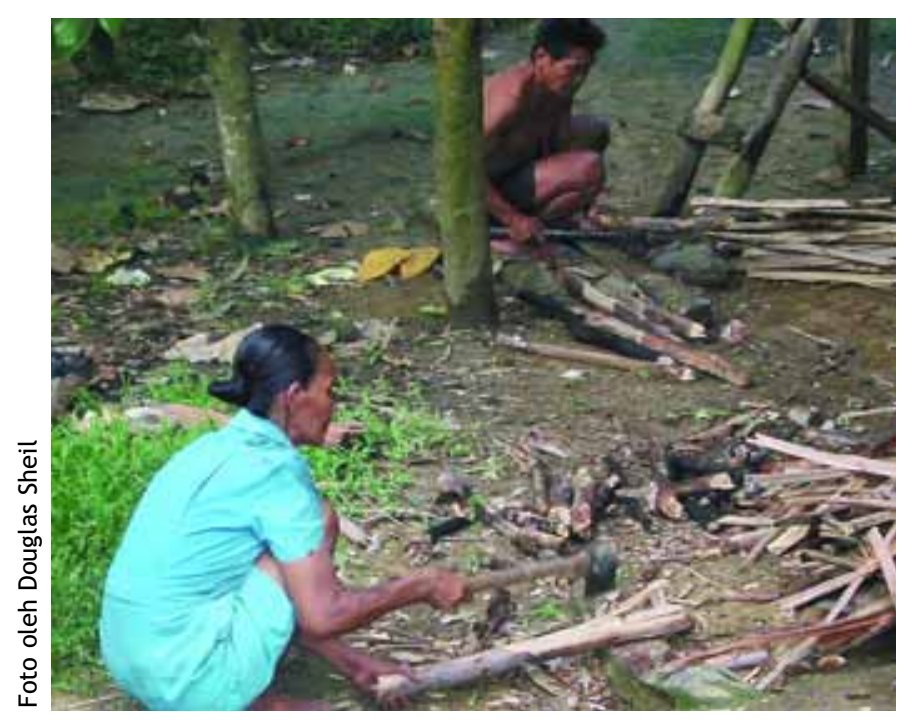

Apa yang dapat dilakukan?

Usaha penanggulangan kemiskinan di Indonesia tidak cukup diarahkan pada masyarakat pedesaan secara umum. Permasalahan kemiskinan di kawasan hutan yang begitu besar mengharuskan adanya perhatian khusus pada kawasan hutan dan masyarakat yang tinggal di hutan dan daerah sekitar hutan. Perlu ada pertimbangan khusus pada pola kepemilikan dan pengelolaan hutan yang ada, peluang ekonomi yang tersedia dari hutan dan kendala-kendala pembangunan di daerah-daerah ini.

Ada empat kegiatan yang dapat meningkatkan perhatian terhadap kemiskinan di kawasan hutan:

- Menciptakan sasaran dan indikator khusus bagi penanggulangan kemiskinan di kawasan hutan sebagai bagian dalam Rencana Jangka Menengah dan SNPK.

- Membentuk kelompok kerja lokal dan nasional untuk pengembangan program untuk memenuhi tujuan tersebut.

- Koordinasi dengan Departemen Kehutanan dan pemerintah lokal untuk memungkinkan akses dan kepastian penguasaan lahan di kawasan hutan.

- Mengembangkan indikator dan sistem pemantauan kemiskinan dan dampak program pemerintah di kawasan hutan sebagai masukan bagi usaha penanggulangan kemiskinan.

\footnotetext{
${ }^{5}$ World Bank, 2002. A Sourcebook for Poverty Reduction Strategies, Vol I. pp. 386-387
}

Kita perlu mengakui adanya petani di kawasan hutan dan kebutuhan mereka akan kepastian penguasaan lahan serta akses ke pasar, informasi dan sarana lain untuk mempertahankan dan meningkatkan penghidupannya. Usaha penanggulangan kemiskinan memerlukan kerjasama para ahli atau pakar dari berbagai sektor antara lain kesehatan, pendidikan, pengembangan usaha skala kecil, pemerintahan, pemberdayaan, dan lingkungan. Tidaklah realistis mengharapkan pejabat kehutanan menjadi pakar kemiskinan. Meskipun demikian, pejabat kehutanan perlu terlibat untuk merasionalisasi pemanfaatan lahan dan mengkoordinasi program-program sosial. Pemanfaatan peta sebagai alat untuk mendiagnosa dan memantau kemiskinan di kawasan hutan akan sangat mendukung penentuan kebijakan dan menetapkan sasaran geografis.

Menurut pedoman SNPK oleh Bank Dunia ${ }^{5}$, kaitan lingkungan (termasuk hutan) dan kemiskinan perlu dipertimbangkan dalam mendiagnosa kemiskinan dan penentuan tindakan yang paling tepat. Dalam pedoman itu juga dianjurkan perlunya identifikasi di mana permasalahan lingkungan relevan bagi kemiskinan melalui penyelidikan hal-hal yang relevan terhadap hutan, antara lain:

- Persentase orang yang bergantung pada hutan untuk penghidupannya dan untuk mengatasi masa kritis

- Pengaruh kebijakan makro-ekonomi terhadap akses sumber daya alam di tingkat lokal

- Penyebaran dan bentuk-bentuk hak atas sumber daya alam

- Perubahan sumber daya alam

- Konflik pemanfaatan sumber daya alam

- Organisasi masyarakat lokal dan lembaga untuk mengelola sumber daya alam

- Kesadaran masyarakat lokal akan hak-hak mereka

- Hubungan masyarakat miskin dengan LSM yang bergerak di bidang lingkungan dan sejauh mana LSM memperhatikan permasalahan yang dianggap penting oleh masyarakat setempat atau melibatkan masyarakat setempat.

Pedoman tersebut juga menyarankan tindakan publik untuk mengatasi permasalahan di kawasan hutan di Indonesia, antara lain: 
- Batalkan kebijakan yang memperbolehkan pertambangan jangka pendek sumber daya alam yang dapat diperbaharui

- Pastikan pengakuan atas fungsi lindung hutan dan keperluan adanya hutan lindung

- Pastikan penghargaan lebih luas atas barang dan jasa yang dihasilkan hutan

- Sediakan stakeholder lokal kepastian akses terhadap sumber daya alam, khususnya hasil hutan

- Kembangkan pengelolaan berbasis masyarakat

- Kembangkan kurikulum pendidikan yang menunjukkan kaitan antara lingkungan masyarakat setempat dan kesejahteraan, untuk meningkatkan kesadaran masyarakat terhadap akibat kerusakan sumber daya.

Juga disarankan:

- Meningkatkan akses terhadap informasi dan keterampilan untuk membantu partisipasi masyarakat lokal dalam pasar dan perolehan manfaat yang lebih banyak

- Membatalkan subsidi yang tersurat maupun tersirat atas pemanfaatan sumber daya alam oleh industri skala besar

- Meningkatkan pelayanan, khususnya kesehatan dan pendidikan, ke daerah terpencil

- Melindungi akses masyarakat setempat terhadap sumber daya yang mereka butuhkan untuk hidup atau sebagai jaring pengaman, misalnya dengan penunjukkan kawasan khusus di wilayah HPH atau wilayah lindung

- Membangun kemampuan kabupaten untuk mengukur dan memantau kemiskinan termasuk secara khusus memantau dampak program mereka terhadap kemiskinan

- Menetapkan mandat Komite Penanggulangan Kemiskinan yang jelas dan anggaran yang cukup untuk melaksanakannya. Libatkan dinas kehutanan dalam KPK.

CIFOR dan Universitas Freiburg, Jerman, bersama Pemerintah Kabupaten Kutai Barat dan Malinau di Kalimantan Timur, sedang mengembangkan pendekatan sederhana untuk penentuan indikator dan alat pantau yang dapat digunakan pemerintah setempat di kawasan hutan. Saat ini kami sedang mengembangkan metode untuk diuji coba, yang diharapkan tahun 2005 siap digunakan. Dalam membahas indikator BPS (Biro Pusat Statistik) dan BKKBN (Badan Koordinasi Keluarga Berencana Nasional), ternyata kabupaten perlu mengembangkan indikator khas daerah untuk dapat menentukan bentuk dan status kemiskinan di daerahnya. Juga perlu ada indikator yang menunjukkan di mana masyarakat lebih sejahtera karena dapat digunakan mengidentifikasi peluang untuk meningkatkan kesejahteraan.

\section{Kesimpulan}

Saat ini Indonesia berpeluang besar untuk dapat menanggulangi kemiskinan dengan memperhatikan bentuk permasalahan kemiskinan di kawasan hutan, bagaimana intervensi pemerintah yang dapat mengatasi permasalahan tersebut secara lintas sektoral, dan memantau perubahan yang terjadi. Memberi perhatian pada hutan dan masyarakat di kawasan hutan mutlak diperlukan dalam penanggulangan kemiskinan di Indonesia. 


\section{Apakah SNPK itu?}

Draft Strategi Nasional Penanggulangan Kemiskinan (SNPK) atau Poverty Reduction Strategy Papers (PRSP) menyajikan gambaran kebijakan dan program makro-ekonomi, struktural dan sosial untuk mendorong pertumbuhan dan menanggulangi kemiskinan suatu negara, disertai kebutuhan dana untuk itu. SNPK dibuat oleh pemerintah melalui proses partisipasi dengan masyarakat madani dan mitra pembangunan, termasuk Bank Dunia dan IMF.

- Didorong oleh negara itu sendiri-melibatkan partisipasi umum masyarakat madani dan pihak swasta dalam semua langkah operasional

- Berorientasi hasil-terfokus pada hasil yang bermanfaat bagi orang miskin

- Komprehensif dalam mengakui sifat kemiskinan yang multi-dimensi

- Berdasar kemitraan-melibatkan partisipasi mitra pembangunan (bilateral, multilateral, dan non-pemerintah) secara terkoordinasi

- Didasarkan atas perspektif jangka panjang untuk penanggulangan kemiskinan.

SNPK meliputi:

- Gambaran umum proses partisipasi yang diterapkan: SNPK menguraikan format, frekwensi, dan tempat diadakannya konsultasi; ringkasan permasalahan utama yang terangkat dan pandangan para peserta; uraian dampak konsultasi terhadap rancangan strategi; dan pembahasan mengenai peran masyarakat madani dalam pemantauan dan pelaksanaan.

- Diagnosa kemiskinan yang komprehensif: Pemahaman mendalam mengenai orang miskin dan tempat tinggalnya memungkinkan SNPK menganalisis kendala terhadap pertumbuhan dan penanggulangan kemiskinan dari segi makro-ekonomi, struktural, sosial dan kelembagaan.

- Prioritas kebijakan makro-ekonomi, struktural dan sosial yang diuraikan secara jelas disertai anggaran yang tepat: Dengan pemahaman yang lebih mendalam mengenai kemiskinan dan penyebabnya, SNPK menetapkan kebijakan makro-ekonomi, struktural dan sosial yang dipersatukan dalam strategi komprehensif untuk mencapai hasil usaha penanggulangan kemiskinan. Agar tidak sekedar berbentuk 'daftar keinginan' maka sejauh mungkin perlu ditetapkan prioritas dan anggaran.

- Sasaran, indikator dan sistem yang tepat bagi pemantauan dan evaluasi kemajuan: SNPK menetapkan tujuan jangka menengah dan jangka panjang untuk hasil usaha penanggulangan kemiskinan (dalam bentuk uang maupun bukan uang), menetapkan indikator kemajuan, dan penentuan sasaran tahunan dan jangka menengah. Indikator dan target tersebut harus konsisten dengan penilaian kemiskinan dan kemampuan lembaga untuk memantau, dan pilihan kebijakan dalam strategi.

Diadaptasi dari http://www.worldbank.org/poverty/strategies

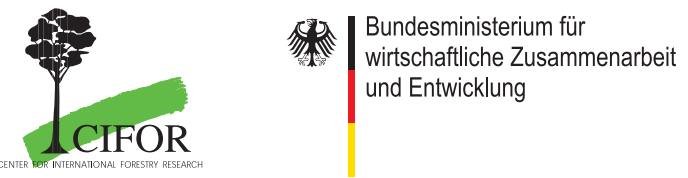

Center for International Forestry Research, CIFOR Alamat kantor: Jalan CIFOR, Situ Gede, Sindang Barang Bogor Barat 16680, Indonesia.

Alamat surat: P.O. Box. 6596 JKPWB, Jakarta 10065 Indonesia
Tel: +62(251) 622622 Fax: +62(251) 622100

E-mail: cifor@cgiar.org

Website: www.cifor.cgiar.org

Foto sampul oleh Lini Wollenberg dan Herlina Hartanto

Program Forests and Governance di CIFOR mengkaji cara pengambilan dan pelaksanaan keputusan berkenaan dengan hutan dan masyarakat yang hidupnya bergantung dari hutan. Tujuannya adalah meningkatkan peran serta dan pemberdayaan kelompok masyarakat yang kurang berdaya, meningkatkan tanggung jawab dan transparansi pembuat keputusan dan kelompok yang lebih berdaya dan mendukung proses-proses yang demokratis dan inklusif yang meningkatkan keterwakilan dan pengambilan keputusan yang adil di antara semua pihak. 